\title{
МОДЕРНІЗАЦІЯ ІНСТРУМЕНТУ ФАКОЕМУЛЬСИФИКАЦІЇ ДЛЯ РІЗНИХ ТИПІВ КОЛИВАНЬ
}

\author{
Наумкіна 3.М., \\ zoyanaumkina@gmail.com \\ Зубчук В. I., к.Т.н., доценТ каф. БМІ \\ grany@meta.ua \\ Факультет біомедичної інженерії \\ Національний технічний університет України \\ «Київський політехнічний інститут імені Ігоря Сікорського» \\ м. Київ, Україна
}

\begin{abstract}
Реферат - На сьогоднішній день новим стандартом в хірургії видалення катарактальних утворень став метод факоемульсифікації, тому необхідно досліджувати головні проблеми та методи іх вирімення задля проведення успішних операчйй.

В роботі було проведено аналіз впливу кожного виду ультразвукових коливань факоголки на утворення термічних пошкоджень ока та втрату оклюзї̈, модернізовано ручний блок факоручки та визначено акустичний тракт для оновленого ультразвукового інструменту факоемульсифікатора.

Розроблена оновлена конструкиія факоголки дозволила провести аналіз технології ї̈ застосування при проведенні хірургічних операчій по видаленню катарактальних мас, їх класифікацію.

Ключові слова - ультразвук, кришталик, катаракта, факоемульсифікація, іригачія, аспірачія, п'єзоелементи.
\end{abstract}

\section{I. ВСТУП}

Природно, людське око функціонує для забезпечення зору шляхом передачі світла через рогівку i кришталик, фокусування зображення сітківці. Через вік або різні патологічні захворювання зір погіршується, утворюються помутніння та нальоти на кришталику. Цей дефект ока в медицині відомий як катаракта[1].

На сьогоднішній день, більшість уражених катарактою кришталиків видаляється за допомогою хірургічної технології під назвою факоемульсифікація [2]. Це метод видалення пошкодженого кришталика за допомогою спеціальної голки (факоголки) або ультразвуку і заміна його на гнучку інтраокулярну лінзу.

Застосування новітніх моделей факоемульсифікаторів дозволять хірургу точно дозувати потужність, довжину і частоту УЗ коливань, вибирати різні режими роботи ультразвукового перетворювача, що модулює як поздовжні, так і складні торсіонні коливання ультразвукової голки, щоб дозувати обсяг подачі розчину в передню камеру ока i швидкість аспірації катарактальник мас[3].
Крім того, модернізація дає можливість хірургу видаляти травматичну катаракту самим м'яким способом, уникнути значної втрати ендотею задніх клітин, вираженого набряку рогівки і їі дистрофії.

\section{II. МЕТА ДОСЛЬДЖЕННЯ}

Мета роботи: на основі аналізу існуючих методів модернізувати робочу частину апарата факоемульсифікації і визначити іii основні акустичні характеристики.

\section{II. МАТЕРІАЛИ І МЕТОДИ}

Традиційно механізм ультразвукового руйнування кришталика полягає у впливі на нього факоголки, що здійснює надшвидкі зворотно-поступальні коливання в ультразвуковому діапазоні.

Ультразвукові коливання можуть мати характер поздовжніх, крутильних або вигинистих, а також поєднуватися в різних пропорціях, утворюючи композитні коливання різної форми в поєднанні 3 вигнутою факоголкоою Кельмана[4].

Основні елементи, які використовуються в факоемульсифікатторах: - ультразвуковий інструмент; 
- порожнистаї голка;

- силіконова манжета;

- концентратор ультразвукових коливань;

- парна кількость п'єзоелементів;

- опорна муфти, розміщена в корпусі;

Робоча частина ультразвукового інструменту у вигляді порожнистої голки виробляє ультразвукові коливання, які використовуються для дроблення i емульсіфікаціi щільних мас кришталиків. Внутрішня порожнина факоголки $\epsilon$ аспіраційним каналом для видалення зруйнованих фрагментів кришталикових мас. Через коаксиально розташовану щодо порожнистої голки силіконову манжету проводиться подача замісної іригаційної рідини.[5]

В сучасних факоемульсифікаторах джерелом ультразвуку найбільш часто $\epsilon$ п'єзоелектричний кристал, осцилюючий 3 частотою 20000-60000 разів в секунду. Ця частота встановлюється виробником факомашіни з урахуванням стандартного ряду частот $22 ; 26.5 ; 44 ; 66$ кГц.

Операція триває кілька хвилин, не вимагає накладення швів і госпіталізації. Факоемульсифікація проводиться під місцевою, крапельною анестезією. Працездатність пацієнту повертається вже на наступний день після проведеного хірургічного втручання.

Етапи операції 3 видалення катаракти[2]:

1. Проводиться дозований розріз шириною в 2,5 міліметра. Доступ до кришталика виконується через зону Лімба (де прозора частина рогівки переходить в непрозору). При цьому використовується одноразове хірургічне лезо. Цей прокол має властивість самогерметизаціі і не вимагає накладення шва. Що значно скорочує час реабілітації і дозволяє уникнути ускладнень.

2. За допомогою ультразвукового зонда проводиться дроблення мутного кришталика на дрібні частинки.

3. Аспірація (відсмоктування) залишкових мас кришталика.

4. Через той же розріз, виробляють імплантацію еластичної інтраокулярної лінзи (штучного кришталика).
Штучний кришталик після імплантації самостійно розкривається і центрується в задній камері ока. По закінченню операції вся маса віскоеластіка вимивається 3 передньої камери ока за допомогою іригаційного розчину. Тривалість операції - від 4 до 10 хвилин..

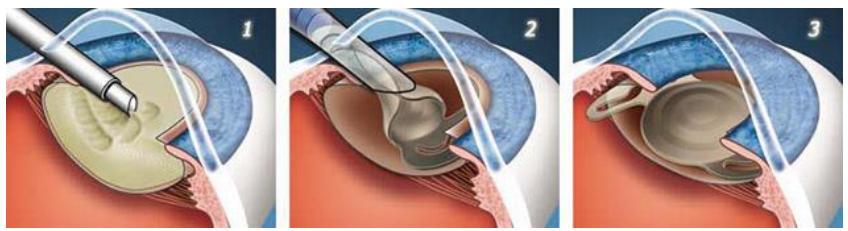

Рис. 1. Схематичне зображення процесу видалення катарактальних мас[6]

У даній схемі: 1 - введення пристрою 3 випромінючою голкою, 2 - видалення катарактальних мас, омивка середовища іригаційною черовиною, 3 - заміна кришталика на інтраокулярноу лінзу.

Протягом усієї процедури іригаційне текуче середовище закачується в око, проходячи між іригаційної втулкою і ріжучою голкою, і виходячи в око на кінчику іригаційної втулки з одного або більше отворів, прорізаних біля кінця трубки.

Іригаційне текуче середовище істотно важливе, оскільки воно запобігає колапсу очного яблука в процесі видалення емульсифікованого кришталика. Воно також охороняє тканини ока від теплової нагрузки, що генерується внаслідок вібрацій ультразвукової ріжучої голки.

Крім того, іригаційне текуче середовище утримує фрагменти емульсифікованого кришталика для аспірації 3 ока. 


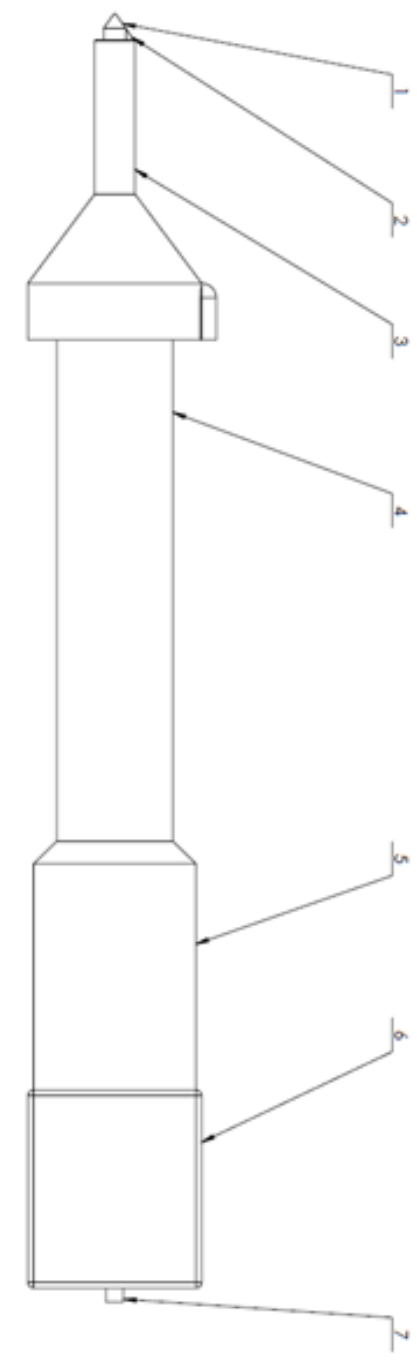

Рис. 2.Схематичне зображення факоручки.

У даній схемі: 1 - ріжуча голка, 2 трубка аспірації, 3 - захисний ковпачок, 4 захисний кожух, 5- рупор, 6 трансформатор(генератор імпульсів), 7іригаційна лінія.

Корпус ручного блоку закінчується на ділянці зменшеного діаметра або носовому конусі на дистальному кінці корпусу. Зазвичай на носовому конусі $€$ зовнішня різьба для прийому порожнистої аспіраційної втулки, що охоплює ріжучу голку по довжині.

Аналогічним чином отвір рупора має внутрішню різьбу на своєму дистальному кінці для прийому зовнішньої різьби ріжучого наконечника. Іригаційна втулка також має отвір 3 внутрішнім різьбленням і загвинчена по зовнішній різьбі носового конуса.

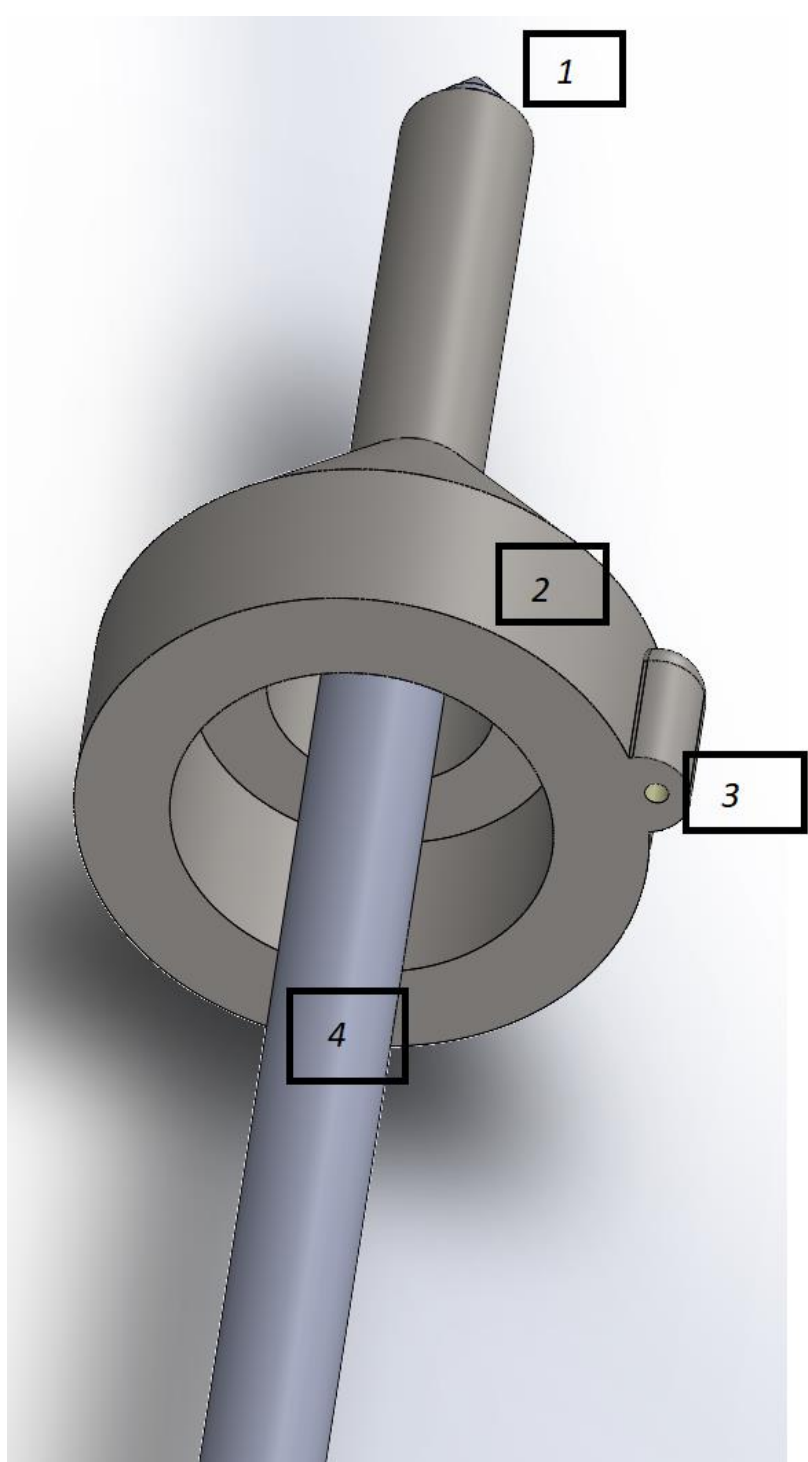

Рис. 3. Модельне зображення факоручки

На даному рисунки позначені головні системні блоки: 1 - ріжуча голка, 2 - захисний ковпачок, 3 - лінія аспірації, 4 -рупор.

В ході проведення факоемульсифікації представленою модернізованою ручкою кінчик ріжучої голки і кінець аспіраційної втулки вводяться в передній сегмент ока через малий розріз в зовнішній тканині ока. Хірург призводить факоголку в зіткнення 3 кришталиком ока, так що вібруючий кінчик фрагментував кришталик. Отримані рештки аспіруються 3 ока через внутрішній отвір захисного кожуха разом 3 іригаційним розчином, що подається в око під час процедури, i надходять в резервуар для відходів.

П'єзоелектричні елементи з'єднані 3 ультразвуковим хвилеводом, до якого 
приєднується ультразвукова голка. Ультразвуковий хвилевід і ультразвукова голка містить безліч діагональних щілин або борозен. Щілини або борозни забезпечують торсіонні коливання ультразвукової голки при порушенні на другий резонансній частоті

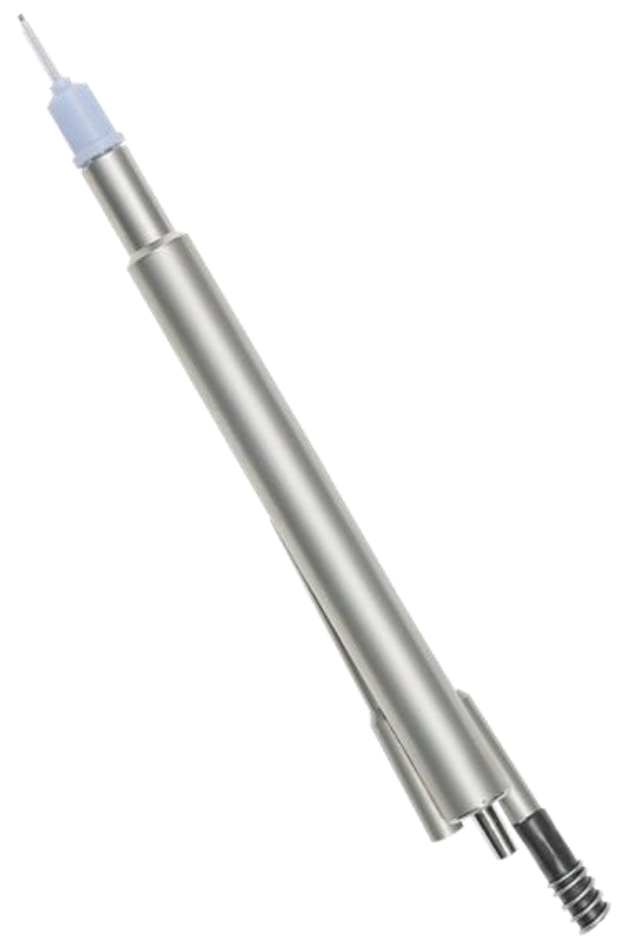

Рис. 4. Прототипна модель ручки факоемульсифікатора[7]

Також при виконанні ультразвукової факоемульсифікації необхідно підтримувати стабільний тиск в передній камері ока, що перешкоджає пошкодженню ендотелію рогівки. У разі ж закупорки аспіраційної магістралі факоаспіратора щільними фрагментами ядра i наступному зменшенні оклюзії, відбувається різке зниження тиску в передній камері i iii колапс, що сприяє підвищеному ризику травматизації тканин ока за рахунок аспірації тканини райдужки i капсули кришталика [8].

Було також розраховано акустичний тракт для ультразвукового інструменту факоемульсифікатора.

Акустичний тракт - це шлях ультразвукової (УЗ) хвилі від випромінюючого перетворювача до біологічної тканини. При цьому ми знехтуємо заломленнями, обумовленими проходженням ультразвуку через контактний провід, безпосередньо приєднаний до п’єзоелемента, протектор, нижню частину корпусу, оскільки товщина вище перелічених елементів дуже мала i заломлення незначне. Також у розрахунку не враховується заломлення УЗ хвиль при проходженні їх через контактне середовище.

\section{Межса факоголка - рогівка}

Кут падіння на межу $45^{\circ}$.

При проходженні У3 коливань від перетворювача до шкіри заломлення не відбувається, тому що між ними знаходиться шар контакного гелю.Тобто: $\theta_{u к i p a ~}=45^{\text {! }}$

\section{Межка рогівка - передня камера}

Кут падіння на межу:

$$
\frac{\mathrm{C}_{\mathrm{p}}}{\mathrm{C}_{\text {П.К }}}=\frac{\sin \theta_{\mathrm{p}}}{\sin \theta_{\text {П.К }}}
$$

$\mathrm{C}_{\mathrm{p}} \quad$ - швидкість проходження ультразвуком рогівки;

$\mathrm{C}_{\text {п.к }} \quad$ - швидкість проходження ультразвуком жирового прошарку;

$\boldsymbol{\theta}_{\mathrm{p}}, \boldsymbol{\theta}_{\text {п.к }}$ - кути відхилення ультразвуку від уявної осі

$$
\begin{gathered}
\theta_{\text {п.к }}=\sin ^{-1}\left[\frac{\mathrm{C}_{\text {п.к }}}{\mathrm{C}_{\mathrm{p}}} * \sin \theta_{\mathrm{p}}\right] \\
=\arcsin \left(\left(\frac{1532}{1640}\right) \sin 45\right) \approx 41.34^{\circ}
\end{gathered}
$$

\section{Межка рогівка - кришталик}

Кут падіння на межу: $\boldsymbol{\theta}_{\text {п.к }}=\mathbf{4 1 . 3 4}$

Аналогічно визначаемо кут, під яким хвиля виходить із шару передньої камери в наступну межу

$$
\begin{gathered}
\theta_{\text {кр }}=\sin ^{-1}\left[\frac{\mathrm{C}_{\text {кр }}}{\mathrm{C}_{\text {п.К }}} * \sin \theta_{\text {п.к }}\right] \\
=\arcsin \left(\left(\frac{1641}{1532}\right) \sin 41,34\right) \approx 45.03^{\circ}
\end{gathered}
$$

Межа кришталик - скловидне тіло Кут падіння на межу: $\boldsymbol{\theta}_{\text {кр }}=\mathbf{4 5 . 0 3}$

$$
\begin{gathered}
\theta_{\text {с. } \mathrm{T}}=\sin ^{-1}\left[\frac{\mathrm{C}_{\text {с.т }}}{\mathrm{C}_{\mathrm{\kappa p}}} * \sin \theta_{\text {кр }}\right] \\
=\arcsin \left(\left(\frac{1532}{1641}\right) \sin 45.03\right) \approx 41.34^{\circ}
\end{gathered}
$$


Межа скловидне тіло-жсовта пляма

Кут падіння на межу: $\boldsymbol{\theta}_{\text {с.т }}=\mathbf{4 1 . 3 4}$

$$
\begin{gathered}
\theta_{\text {ж.П }}=\sin ^{-1}\left[\frac{\mathrm{C}_{\text {ж. }}}{\mathrm{C}_{\text {с. } \mathrm{T}}} * \sin \theta_{\text {с. } \mathrm{T}}\right] \\
=\arcsin \left(\left(\frac{1510}{1532}\right) \sin 41.34\right) \approx 40.62^{\circ}
\end{gathered}
$$

\section{Межа жовта пляма-сітківка}

Кут падіння на межу: $\boldsymbol{\theta}_{\text {ж.п }}=\mathbf{4 0 . 6 2}$

$$
\begin{gathered}
\theta_{\mathrm{c}}=\sin ^{-1}\left[\frac{\mathrm{C}_{\mathrm{c}}}{\mathrm{C}_{\text {ж. }}} * \sin \theta_{\text {ж.П }}\right] \\
=\arcsin \left(\left(\frac{1490}{1510}\right) \sin 40.62\right) \approx 39.97^{\circ}
\end{gathered}
$$

\section{Межка сітківка-склера}

Кут падіння на межу: $\boldsymbol{\theta}_{\text {ж.п }}=\mathbf{3 9 . 9 7}$

$$
\begin{gathered}
\theta_{\mathrm{cK}}=\sin ^{-1}\left[\frac{\mathrm{C}_{\mathrm{cK}}}{\mathrm{C}_{\mathrm{c}}} * \sin \theta_{\mathrm{c}}\right] \\
=\arcsin \left(\left(\frac{1680}{1490}\right) \sin 39.97\right) \approx 46.41^{\circ}
\end{gathered}
$$

Формули акустичного тракту враховує променеву картинку даного модернізованого блоку факоголки, характеристики спрямованості випромінювання-прийому та структурну схему акустичного тракту (акустичні характеристики та розміри середовищ, через які проходить акустичний промінь).

\section{IV. РЕЗУЛЬТАТИ ТА ОБГОВОРЕННЯ}

У роботі, виходячи із отриманих даних, був вибраний метод для модернізації робочого інструменту факоемульсифікації, а також проведено дослідження акустичного тракту для отримання значень, на основі яких можна проводити подальший аналіз доцільності застосування модернізованого блоку, а саме визначення коефіцієнтів прямого та зворотного УЗ п'єзоефектів, розрахунок частоти та швидкості роботи факомашини.

\section{V. ВИСНОВКИ}

У ході даної роботи аналіз існуючих методів лікування катаракти дав поштовх до виокремлення головних проблем традиційної факоемульсифікації, які потребують вирішення методами комбінації різних типів коливань, проаналізовано головні особливості видалення катарактальних мас із зіниці.

В статті розроблено схематичну та 3D модель факоручки на основі прототипу.

Крім того було проведено розрахунок акустичного тракту по переходу ультразвукових хвиль від резонуючої голки до склери, що дозволив отримати значення до порівняння їх уже 3 відомими та зробити висновок, що модернізована модель факоголки $\epsilon$ більш точною в проведенні хірургічних операцій.

\section{ПЕРЕЛІК ПОСИЛАНЬ}

[1] Мобильное устройство для введения интраокулярной линзы: пат.№ 2538633С2; заяв.10.01.2010; опуб.27.05.2010 [Електронний ресурс]. - Режим доступу до ресурсу: https://patents.google.com/patent/RU2538633C2/ru?oq=RU25 $\underline{38633 \mathrm{C} 2}$ (дата звернення 12.05.2019).

[2] Ультразвуковая Факоэмульсификация: [Електронний peсурс]. - Режим доступу до ресурсу: https://mocentro.com/katarakta/fakoemulsifikaciya/

[3] Азнабаев Б. М., Мухамадеев Т. Р., Дибаев Т. И. Ультразвуковая факоэмульсификация на основе непродольных колебаний // Медицинский вестник Башкортостана. $2012 . \quad$ №6. URL: https://cyberleninka.ru/article/n/ultrazvukovayafakoemulsifikatsiya-na-osnove-neprodolnyh-kolebaniy (дата обращения: 14.05.2020).

[4] Азнабаев, Б.М. Ультразвуковая хирургия катаракты факоэмульсификация / Б.М. Азнабаев. - М.: Август Борг, 2005. - 136 c..

[5] Ультразвуковой инструмент факоэмульсификатора: пат.№ 2470620; [Електронний ресурс]. - Режим доступу до pecypcy: https://findpatent.ru/patent/247/2470620.html (дата звернення 14.05.2019).

[6] Операция по удалению катаракты: [Електронний ресурс]. - Режим доступу до ресурсу: http://neoskin.com.ua/hirurgicheskoe-lechenie-katarakty.html (дата звернення 14.05.2019).

[7] Ручка для факоэмульсификации: [Електронний ресурс]. Режим доступу до ресурсу: https://dorcglobal.com/ru/produkt/ruchka-dlyafakoemulsifikacii (дата звернення 14.05.2019).

[8] Иванова Е. В. МЕХАНИЧЕСКИЙ ФАКОАСПИРАТОР ДЛЯ РАЗРУШЕНИЯ И АСПИРАЦИИ ХРУСТАЛИКА ПРИ КАТАРАКТЕ / Е. В. Иванова // Международный научно-исследовательский журнал. - 2018. - № 3 (69). C. 117-120. - URL: https://researchjournal.org/medical/mexanicheskij-fakoaspirator-dlyarazrusheniya-i-aspiracii-xrustalika-pri-katarakte/ обращения: 14.05.2020. ). doi: 10.23670/IRJ.2018.69.009 


\title{
МОДЕРНИЗАЦИЯ ИНСТРУМЕНТА ФАКОЕМУЛЬСИФИКАЦИИ ДЛЯ РАЗЛИЧНЫХ ТИПОВ КОЛЕБАНИЙ
}

Наумкина 3.H., zoyanaumkina@gmail.com

Зубцук В. И., к.т.н., доцент каф. БМИ

grany@,meta.ua

Факультет биомедицинской инженерии Национальный технический университет Украины «Киевский политехнический институт имени Игоря Сикорского»

г. Киев, Украина

\footnotetext{
Реферат - На сегодняшний день новым стандартом в хирургии удаление катарактальных образований стал метод факоэмульсификации, поэтому необходимо исследовать главные проблемы и методы их решения для проведения успешных операчий.

В работе был проведен анализ влияния каждого вида ультразвуковых колебаний факоиглы на образование термических повреждений глаза и потерю окклюзии, модернизировано ручной блок факоручки и определен акустический тракт для обновленного ультразвукового инструмента факоэмульсификатора.

Разработанная обновленная конструкиия факоиглы позволила провести анализ технологии ее применения при проведении хирургических операций по удалению катарактальных масс, их классификачию.

Ключевые слова - ультразвук, хрусталик, катаракта, факоэмульсификация, ирригация, аспирация, пьезоэлементы.
}

UDC 615.837 .3

\section{THE PHACOEMULSIFICATION TOOL MODERNIZATION FOR DIFFERENT TYPES OF OSCILLATIONS}

\author{
Zoia Naumkina \\ zoyanaumkina@gmail.com \\ Zubchuk VI, Ph.D., Professor BMI \\ grany@meta.ua \\ Faculty of Biomedical Engineering \\ National Technical University of Ukraine \\ "Igor Sikorsky Kyiv Polytechnic Institute" \\ Kyiv, Ukraine
}

\begin{abstract}
Today, the phacoemulsification method has become a new standard in cataract surgery. Ultrasonic vibrations, which came from different nature and also combined in different proportions were analyzed.

The article provides an overview of the technology for carrying out surgical operations to remove cataract masses, their classification and a possible way to modernize the pen is seen.

The topic of the article is related to scientific research in the field of healthcare and medical technology.

.Keywords - ultrasound, lens, cataract, phacoemulsification, irrigation, aspiration, piezoelectric elements.
\end{abstract}

